\title{
THE GRASS POLLEN SEASON DYNAMICS IN RELATION TO THE METEOROLOGICAL CONDITIONS IN CRACOW, SOUTHERN POLAND, 1991-2008
}

\author{
Dorota Myszkowska \\ Department of Clinical and Environmental Allergology, Jagiellonian University Medical College, \\ Śniadeckich 10, 31-531 Cracow, Poland \\ e-mail:dmyszkow@cm-uj.krakow.pl
}

Received: 2.10 .2010

\begin{abstract}
The aim of the study was to analyse the grass pollen season dynamics in Cracow in 1991-2008 and to find the relationship between the meteorological conditions and season parameters. The pollen season started on average on the 138th day of the year ( \pm 10 days) and ended on the 211 th day ( \pm 10 days). The median of the SPI value (calculated by the $95 / 90 \%$ method) was 2041 , peak concentration $-111 \mathrm{pgm}^{-3}$ (achieved on average on the 34 th day of the season/173th day of the year). The average temperature in April-May showed the greatest effect on the start and end of the season (negative correlation). $\mathrm{T}_{\text {mean }}$ of the third decade of June influenced the season end ( $\mathrm{r}_{\mathrm{s}}$ negative). $\mathrm{T}_{\text {mean }}$ of April-May correlated negatively with the time of peak concentration. Rainfall in January and April influenced the season start. Relative sunshine in March-April was related to the season start, in the third decade of June it was related to the season end (negative correlation), in March-April it influenced the time of peak concentration (positive correlation), while in January-March the peak concentration (positively). Cloudiness in February-May and also in the third decade of June had an impact on the season end and time of peak concentration (positive correlation). Humidity in February influenced the season start (negatively). The SPI value was influenced by relative sunshine (positively) in February-May, by humidity in April, and cloudiness in February-March (negatively).
\end{abstract}

Key words: aerobiology, grass pollen, pollen seasons, meteorological parameters, Cracow

\section{INTRODUCTION}

The Poaceae family is one of the most abundant families among different species of the Polish flora, similarly as it is in the whole Northern Hemisphere. It is assumed that about $4 / 5$ of the Polish flora comprises young migratory elements relative to the older ones, for example the Mediterranean flora. It also applies to grasses which are a regular part of different plant communities (B a l c e rki e w i c z, 2007). F r e y (2007) reported that the following grass genera are the most frequent in Poland: Festuca (36), Bromus (26) and Poa (20), while less frequent are: Avena (9), Agrostis, Phleum and Hordeum (8 species each). In Cracow significant land use changes have occurred that have resulted in a different composition of the urban flora. The presence of particular natural communities (meadows) in the area of Cracow does not exceed $1 \%$ of surface area, except in rye grass meadows ( $A r$ rhenatheretum elatioris tipicum) (3.21\%). A great part of this area is covered by thicket (4.68\%), fallow communities (Artemisietea) (13.28\%) as well as lawns and green belts (10.08\%) (D u b i e 1, 2008).

The worldwide spread of grasses has the impact on human health, because grass allergens provoke the symptoms of allergic rhinitis in sensitive patients. It is reported that in Europe more than $40 \%$ of the population suffer from pollen allergy, and grass pollen allergens are the main cause of allergy symptoms in Central and Southern Europe (D' A m a t o et al. 2007). In Cracow about $80 \%$ of patients with pollen allergy are sensitive to grass allergens, and the intensity of allergy symptoms increases in May-August (O b t u ło w i c z et al. 1991; M y s z k ow s k a et al. 2002). The time of occurrence of grass pollen in the air (60 up to 120 days "long season") (S z c z e p a n e k, 2004) has an impact on the manifestation of allergy symptoms in patients (M y s z k ow s k a et al. 2007).

In many papers relating to aerobiological monitoring in Europe, including Poland, their authors reported on the influence of local meteorological conditions on the grass season characteristics ( $\mathrm{S}$ á n c h e z Mesa et al. 2003; Peternel et al. 2006; S t a ch et al. 2008; G a r c i a - M o z o et al. 2010). Large-scale 
research carried out in Europe showed that the North Atlantic Oscillation substantially influenced the pollen seasons (S m i th et al. 2009). The geographical location, especially latitude, is a factor of great importance affecting plant behavior ( $\mathrm{V}$ a le n cia-B a r rera et al. 2001). S m it h et al. (2009) reported that when using the latitude as a factor, about $87 \%$ of variations in grass pollen season start dates could be explained. Therefore, studies on the relationship between the pollen season and meteorological parameters in a given region are really important.

The results obtained on the basis of short-time series allow to make preliminary estimation of this relationship (S t a c h, 2000; V a le n c i a - B a r rera et al. 2001; K a s przy k, 2006; P i otrow s ka, 2006). On the other hand, long-time series (at least 10 years) make the results of analyses more reliable (S án chez-Mes a et al. 2003; S pi ek s ma et al. 2003; Gioulekas et al. 2004; J at o et al. 2009; Garcia-Mozo et al. 2010).

In Cracow aerobiological monitoring has been performed since 1982. The gravimetric observations carried out in 1982-1997 showed that grass pollen, except Secale pollen, occurred in the air during the whole year, but higher concentrations were noted from the middle of April to the middle of October. The percentage of grass pollen concentration in the annual total amounted to $8.1 \%$ (S z c z e p a n e k, 2004). A statistically significant influence of the majority of meteorological parameters (temperature, rainfall, humidity) on the pollen fall was found (W a l a n u s, 1994).

In 1989 the volumetric method of sampling was introduced in Cracow and the preliminary results in 2001-2005 showed that the grass pollen season started usually on 1-15 of May. The season lasted from 97 to 117 days and the annual total did not differ in the study years (M y s z k ow s k a, 2006). Analysing the grass pollen seasons in 1991-2007, Pi otrowic z and M y s z k o w s k a (2008) established that in 1997 an extremely high annual total was reached because of the favourable weather conditions (mean rainfall in July (229 mm) was higher than the long-term average of 101 $\mathrm{mm}$, mean temperature in June-August was slightly lower (by $0.9^{\circ} \mathrm{C}$ ) than the mean value in 1991-2007 $\left(18.7^{\circ} \mathrm{C}\right)$ and there were more sunny days than usual).

The aim of this study was to analyse the grass pollen season dynamics in Cracow in 1991-2008 and to investigate the influence of meteorological conditions on the season parameters.

\section{MATERIALS AND METHODS}

\section{Study site}

Cracow (220 $\mathrm{m}$ a.s.1., 5004' N, 1958' E) is located in the Małopolska province (Southern Poland) and surrounded by farmlands and forests. To the north of Cracow, farmlands are found with small forest communities. To the south and east of Cracow, there are roughly equal areas of farmlands and forests. Forest communities prevail to the west of the city. The centre of Cracow is characterized by high building density, with the city centre surrounded by a green belt with Aesculus sp., Tilia sp., Acer sp., Populus sp. and other ornamental trees and shrubs.

Cracow is influenced by air masses of polarmaritime origin coming from over the Northern Atlantic, which bring thaw, an increase in cloudiness and snow in winter as well as chilling, an increase in cloudiness and rainfall in summer. The mean annual air temperature in Cracow in the 20th century amounted to $8.7^{\circ} \mathrm{C}$, while 2000 was the hottest year $\left(11^{\circ} \mathrm{C}\right)$ (P i o t r o w i c z, 2007). The coldest month is January and the hottest - July (mean monthly temperatures $2.1^{\circ} \mathrm{C}$ and $18.9^{\circ} \mathrm{C}$, respectively). Sunshine duration per day is 3.9 hours although from April to September it is 5.7 hours (W o ś, 1999). Mean annual precipitation is approximately $700 \mathrm{~mm}$. The highest rainfall level is recorded in summer (June, July, August). In the annual cycle, about $40 \%$ of rain falls in these months in Poland. Mean annual humidity is $79 \%$ and wind from the westerly direction prevails. The mean wind velocity is relatively low, about $2.9 \mathrm{~ms}^{-1}$ (W o ś, 1999).

A heat island occurs in Cracow; its intensity in the city centre achieves $1.2^{\circ} \mathrm{C}$ on average. The heat island is responsible for a change in the thermal season duration in the year. In the center of the city, summer is longer by 25 days and winter is shorter by 23 days than in the suburban area. Also, in the centre of Cracow the number of hot days is higher by $10-11$, and accumulated rainfall is higher than in the suburban area (M a t u s z k o, 2007).

Meteorological data were provided by the Research Station of the Dept. of Climatology, Institute of Geography and Spatial Management, Jagiellonian University (5004'N, 1958' E, $206 \mathrm{~m}$ a.s.1.). Weather observations has been carried out since 1792 . The Station is located in the immediate vicinity of the monitoring site.

\section{Grass pollen counts}

Grass pollen concentration has been monitored since 1991 using a volumetric sampler (Burkard trap in 1991-2003, Lanzoni trap in 2004-2008). The sampler was located on the roof top of the Śniadecki Collegium building, $20 \mathrm{~m}$ above ground level, in the center of the city. Airborne pollen grains were sampled continuously. Melinex tape used for catching pollen grains was replaced every Tuesday at 8 a.m. and cut into segments corresponding to $24 \mathrm{~h}$ periods. Two different counting methods were employed. From 1991 to 1999 , pollen grains were counted along 12 latitu- 
dinal transects. From 2000 to 2008, this method was changed into counting along 4 longitudinal transects according to the method used by the Spanish Aerobiology Network (REA) (C a rĩ̃ a n o s et al. 2000). Pollen grains were counted using a light microscope at a 400x magnification and daily average pollen counts were expressed as pollen grains per cubic meter of air.

\section{Analysis}

Pollen seasons were calculated using the $95 \%$ and $90 \%$ methods for the start and end of the season, respectively. The start of the season was defined as the date when $2.5 \%$ of the seasonal cumulative pollen count was trapped and the end of the season as the date when $95 \%$ of the seasonal cumulative pollen count was reached. The comparison between the season parameters calculated by the method mentioned above and the parameters calculated for raw data showed that the time of occurrence of pollen grains shortened by almost half, because of the "cutting" of low concentrations mainly in the end of the post-peak period. The season duration calculated by the $95 / 90 \%$ method accounts for $46 \%$ of the total pollen season in the year (original data) (Fig. 1 ). The number of days without pollen grains before the peak day amounts to $6 \%$, while after the peak this number is $3 \%$. When the $95 / 90 \%$ method was applied, a majority of days without pollen was excluded.

Apart from the season start and end date, the following season parameters were calculated: season duration, annual total, SPI value (Seasonal Pollen Index - the sum of pollen grains calculated in the given season), the maximum pollen concentration in the season and the day of maximum concentration. Descriptive statistics was used to calculate the season characteristics (minimum, maximum, quartile 1 and 3; arithmetic mean, confidence interval for arithmetic mean, standard deviation, median and coefficient of variation). To find the relationship between season and meteorological parameters, the following meteorological parameters were used:

- Air temperature - minimum, maximum and mean daily temperature was used as the input data. Mean daily temperature was calculated by the formula: $\mathrm{tmax}+\mathrm{tmin}+\mathrm{t} 7+\mathrm{t} 19 / 4(\mathrm{t} 7$ - temperature at 7 a.m., t19 - temperature at 7 p.m.)

- Rainfall (mm) - „0” means no lack of rain; ,0.01” means a trace of rain

- Relative humidity - the mean value calculated by the formula $(2 \mathrm{x} \mathrm{f7}+\mathrm{f} 13+\mathrm{f} 19) / 4(\mathrm{f} 7$ - humidity measured at 7 a.m., f13 - humidity measured at 1 p.m., f19 - humidity measured at 7 p.m.)

- Cloudiness $(\%)$ - the mean value calculated on the basis of three measurements: at 6, 12 and 18 UTC. $100 \%$ - full cloudiness, $0 \%$ - cloudless sky. A 0-10 scale was used.
- Relative sunshine - the number of sunshine hours in a given day related to the length of the day (hours from sunrise to sunset).

The 10-day mean and monthly mean of the meteorological data were calculated. Spearman's rank correlation test was used to find the relationship between season and meteorological parameters (STATISTICA program, version 9.0). Only statistically significant correlation coefficients were taken into consideration.

\section{RESULTS}

Mean season duration was 74 days; the shortest season was noted in 1994 (55 days), the longest one in 2004 (87 days) (Table 1, Fig. 1). Compared to the original data, the pollen season started on average 15 days later, and was more than 67 days shorter. The season started usually on the 18 of May, and ended on the 31 of July (Table 1, Fig. 2). A weak decreasing linear trend (statistically significant) was found in the season start date $\left(\mathrm{r}_{\mathrm{s}}-0.442 ; \mathrm{p}<0.05\right)$ (Fig. 3). The highest SPI value was reached in 1997, the lowest one in 1995 (Fig. 4). No significant increasing or decreasing trend in the SPI value and peak concentration was found. After excluding the SPI value in 1997 (the highest value in the examined period) from the analysis, a significant trend was found $\left(\mathrm{r}_{\mathrm{s}} 0.691 ; \mathrm{p}<0.05\right)$.

When considering the coefficient of variation (V\%), it was noted that the peak concentration, annual total and SPI varied strongly from year to year, although the season start and end dates as well as the day of peak concentration were less variable parameters (Table 1).

The pollen season curves were asymmetric with domination of right asymmetry (the mean number of days in the pre-peak period was lower (49 days) than in the post-peak period (100 days)). The difference between the pre- and post-peak period was also influenced by the number of days with no pollen grains (16\% before the peak day, 32\% after the peak day). When the $95 / 90 \%$ method was applied, the number of days with no pollen before the peak day amounted to $6 \%$, while after the peak day it amounted to $3 \%$, on average. A majority of days with no pollen was excluded when using this method. One peak concentration during the season was observed (e.g. 1993, 2001-2003, 2007) (Fig. 5a), or more days with comparable high concentrations were observed (e.g. 1996, 1998, 2008) (Fig. 5b). The high concentration days were scattered throughout the season or concentrated together. A statistically significant correlation between SPI value and peak concentration $\left(\mathrm{r}_{\mathrm{s}} 0.741\right.$; $\mathrm{p}<0.05$ ) was found (Fig. 6).

The influence of the meteorological parameters on the season parameters was both negative 
Table 1

The characteristics of seasonal parameters calculated using 95/90\% method (Cracow, 1991-2008)

\begin{tabular}{|c|c|c|c|c|c|c|}
\hline \multirow{2}{*}{ Characteristics } & \multirow{2}{*}{$\begin{array}{c}\text { Season start } \\
\text { day* }\end{array}$} & \multirow{2}{*}{$\begin{array}{c}\text { Season } \\
\text { end day* }\end{array}$} & \multirow{2}{*}{$\begin{array}{l}\text { Duration } \\
\text { (days) }\end{array}$} & \multirow{2}{*}{$\begin{array}{c}\text { SPI } \\
\left(\mathrm{pgm}^{-3}\right)\end{array}$} & \multicolumn{2}{|c|}{ Peak day } \\
\hline & & & & & $\mathrm{Pgm}^{-3}$ & Day* \\
\hline Min & 124 & 196 & 60 & 784 & 58 & 148 \\
\hline$Q_{1}$ & 131.50 & 205.00 & 68.00 & 1149.00 & 86.75 & 160.00 \\
\hline me & 137.50 & 211.50 & 72.00 & 2041.00 & 111.00 & 176.50 \\
\hline$Q_{3}$ & 146.25 & 217.00 & 78.00 & 2575.00 & 158.00 & 183.50 \\
\hline $\max$ & 155 & 230 & 102 & 5524 & 437 & 192 \\
\hline $\bar{x}$ & 138.39 & 211.33 & 73.94 & 1998.06 & 137.28 & 172.78 \\
\hline$s$ & 9.58 & 9.66 & 10.17 & 1133.09 & 87.41 & 14.44 \\
\hline$V \%$ & 6.92 & 4.57 & 13.76 & 56.71 & 63.68 & 8.36 \\
\hline$[-95 \% ;+95 \%]$ & $\begin{array}{c}133.62 \\
43.15\end{array}$ & $206.53 ; 216.14$ & $\begin{array}{l}68.89 \\
79.00\end{array}$ & $\begin{array}{l}1434.59 \\
2561.53\end{array}$ & $\begin{array}{l}93.81 ; \\
180.75\end{array}$ & $\begin{array}{l}165.60 ; \\
179.96\end{array}$ \\
\hline
\end{tabular}

* the consecutive days from the 1st January

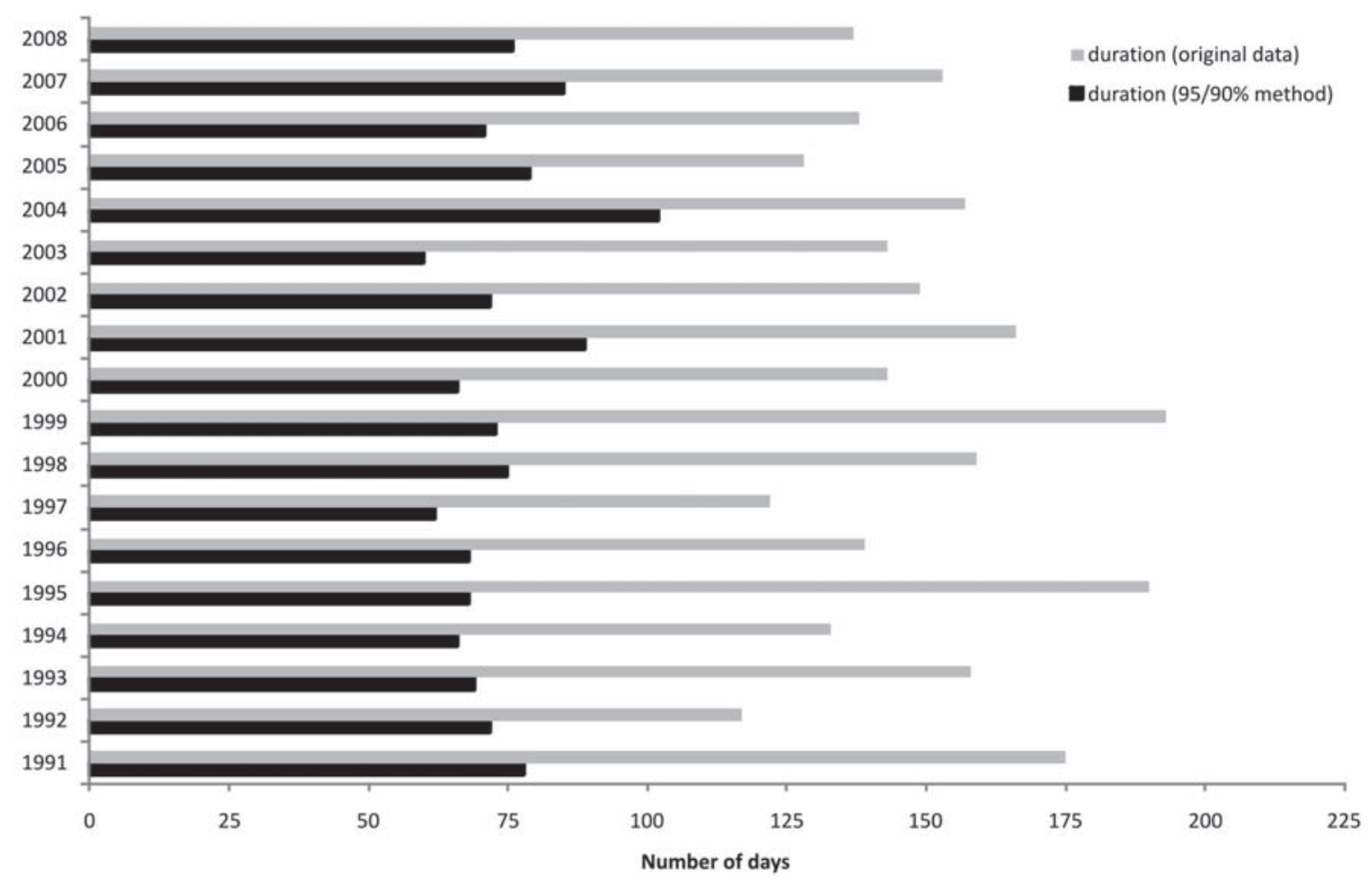

Fig. 1. The grass pollen season duration calculated using the $95 / 90 \%$ method and the whole grass pollen season (original data) (Cracow, 1991-2008) 
Table 2

Significant Spearman's correlations between season parameters and meteorological parameters in Cracow in 1991-2008. Only the highest values of correlation coefficients were selected. *Correlation is significant at the 0.05 level (2-tailed). ** Correlation is significant at the 0.01 level (2-tailed)

\begin{tabular}{|c|c|}
\hline Season parameter vs meteorological parameter & Correlation coefficient \\
\hline \multicolumn{2}{|l|}{ Dependent variable: season start } \\
\hline 10-day mean daily temperature days $101-110$ from $1 \mathrm{Jan}$ & $-0.776 * *$ \\
\hline Mean April daily temperature & $-0.568 *$ \\
\hline Mean April-May daily temperature & $-0.502 *$ \\
\hline 10-day mean daily rainfall days $11-20$ from 1 Jan & $-0.619 * *$ \\
\hline Mean April daily rainfall & $0.551^{*}$ \\
\hline Mean March-April daily relative sunshine & $-0.490 *$ \\
\hline 10-day mean daily relative humidity days $41-50$ from 1 Jan & $-0.486^{*}$ \\
\hline \multicolumn{2}{|l|}{ Dependent variable: peak day } \\
\hline 10-day mean daily temperature days $111-120$ from 1 Jan & $-0.526^{*}$ \\
\hline Mean April-May daily temperature & $-0.514 *$ \\
\hline 10-day mean daily relative sunshine days $91-100$ from $1 \mathrm{Jan}$ & $0.503 *$ \\
\hline 10-day mean daily relative sunshine days $111-120$ from 1 Jan & $-0.512 *$ \\
\hline 10-day mean daily relative humidity days $121-130$ from 1 Jan & $0.614 * *$ \\
\hline 10-day mean daily cloudiness days $111-120$ from 1 Jan & $0.493 *$ \\
\hline 10-day mean daily cloudiness days $121-130$ from 1 Jan & $0.476^{*}$ \\
\hline \multicolumn{2}{|l|}{ Dependent variable: season end } \\
\hline 10-day mean daily temperature days $101-110$ from 1 Jan & $-0.629 * *$ \\
\hline 10-day mean daily temperature days $141-150$ from 1 Jan & $-0.568 *$ \\
\hline 10-day mean daily temperature days $171-180$ from 1 Jan & $-0.510 *$ \\
\hline Mean April-May daily temperature & $-0.635^{* *}$ \\
\hline 10-day mean daily relative sunshine days $171-180$ from 1 Jan & $-0.488 *$ \\
\hline 10-day mean daily relative humidity days $171-180$ from 1 Jan & $-0.616^{* *}$ \\
\hline 10-day mean daily cloudiness days $121-130$ from 1 Jan & $0.559 *$ \\
\hline 10-day mean daily cloudiness days $171-180$ from 1 Jan & $0.524 *$ \\
\hline Mean March-April daily cloudiness & $0.622 * *$ \\
\hline Mean March-May daily cloudiness & $0.670 * *$ \\
\hline Mean February-May daily cloudiness & $0.683 * *$ \\
\hline \multicolumn{2}{|l|}{ Dependent variable: SPI value } \\
\hline 10-day mean daily relative sunshine days $61-70$ from 1 Jan & $0.556^{*}$ \\
\hline Mean February-May daily relative sunshine & $0.478 *$ \\
\hline 10-day mean daily relative humidity days $61-70$ from 1 Jan & $-0.491 *$ \\
\hline 10-day mean daily relative humidity days $91-100$ from 1 Jan & $-0.586^{*}$ \\
\hline 10-day mean daily cloudiness days $61-70$ from 1 Jan & $-0.557 *$ \\
\hline Mean March daily cloudiness & $-0.709 * *$ \\
\hline \multicolumn{2}{|l|}{ Dependent variable: peak concentration } \\
\hline Mean January-March daily relative sunshine & $0.519 *$ \\
\hline Mean March daily cloudiness & $-0.568 *$ \\
\hline Mean February-March daily cloudiness & $-0.594 * *$ \\
\hline Mean February-May daily cloudiness & $-0.594 * *$ \\
\hline Mean January-May daily cloudiness & $-0.599 * *$ \\
\hline
\end{tabular}




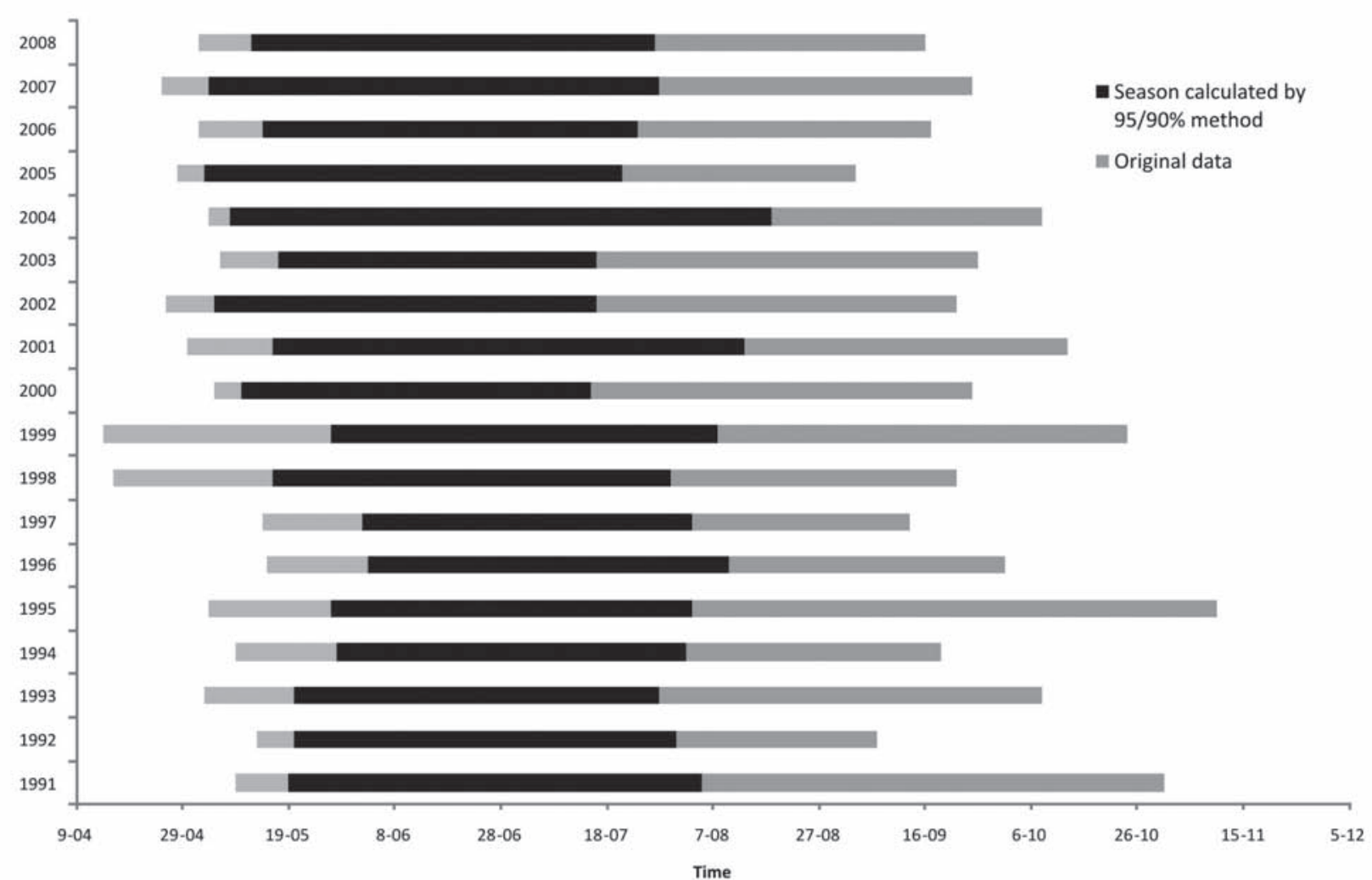

Fig. 2. The calculated grass pollen season (95/90\% method) and days with pollen before and after the calculated season (Cracow, 1991-2008)

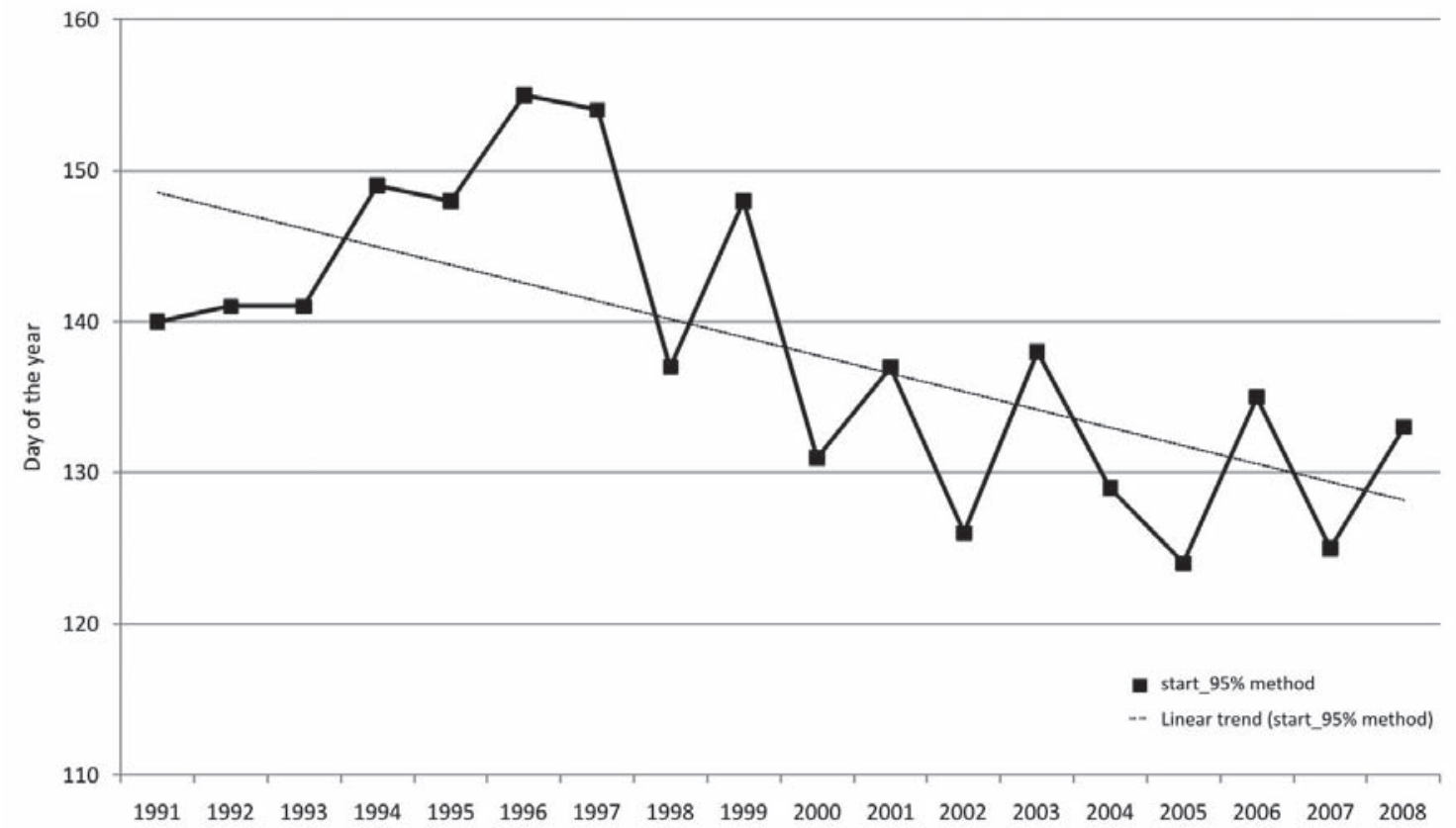

Fig. 3. The start of the grass pollen seasons in Cracow in 1991-2008 calculated by the $95 \%$ method $\left(\mathrm{r}_{\mathrm{s}}=0.442 ; \mathrm{p}<0.05\right.$; $\mathrm{R}_{2}=0.673$ ) 


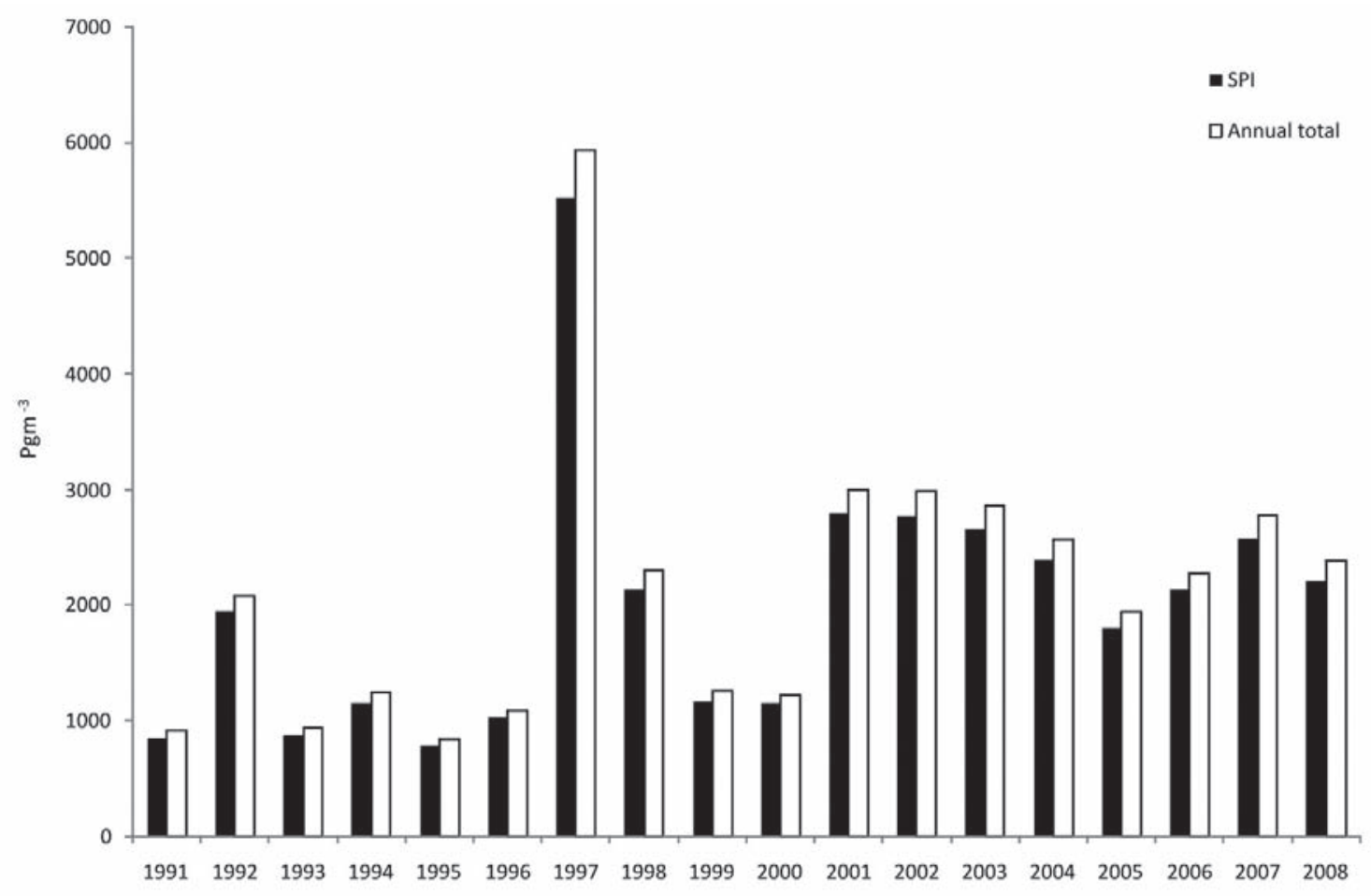

Fig. 4. Annual pollen total and SPI value of grass pollen concentrations in Cracow in 1991-2008

( $\mathrm{r}_{\mathrm{s}}$ ranged from -0.78 to -0.46$)$ and positive $\left(\mathrm{r}_{\mathrm{s}}\right.$ ranged from 0.46 to 0.70 ) (Table 2). Only the highest values of the statistically significant correlation coefficients were selected. Mean temperature in April-May had the strongest impact on the season start and end. The end of the season was also influenced by mean temperature in the third decade of June (negatively). Mean temperature in April-May also influenced the time of the peak day (negatively). Relative sunshine in March-April was related to the season start, in the third decade of June it was related to the season end (negative correlation), in March-April it was related to the time of the peak day ( $\mathrm{r}_{\mathrm{s}}$ positive), although relative sunshine in January-March influenced the peak concentration (positively). Cloudiness in FebruaryMay and in the third decade of June had an impact on the season end and the day of peak concentration (positive correlation). Humidity in February influenced the season start $\left(\mathrm{r}_{\mathrm{s}}\right.$ negative), humidity in the third decade of June influenced the season end ( $r_{s}$ positive). The SPI value was influenced by relative sunshine $\left(\mathrm{r}_{\mathrm{s}}\right.$ positive) in February-March, by humidity in April, and by cloudiness in February-March ( $r_{s}$ negative).

\section{DISCUSSION}

In Europe the highest grass pollen concentrations are noted in June (D' A m a t o et al. 2007), but the pollen season start varies with time both in a given region (E mberlin et al. 1993, 1999; Peternel et al. 2006; Jato et al. 2009; Garcia-Mozo et al. 2010) and in different parts of the continent. In the Mediterranean region, the grass pollen season may start at the beginning of April, while in Northern and Central Europe the season starts at the beginning of May. The mean difference in the season start between Northern and Southern Europe amounts to 73 days (the research was carried out in 12 monitoring sites) (E m berlin et al. 2000). In Southern Europe (Bologna, Perugia, Cordoba), the grass pollen usually starts on the 116th-130th day of the year, in Central and Western Europe (Vienna, Klagenfurt, Leiden) on the 139th150th day of the year, but in Northern part of Europe (Turku, Oulo, Kevo) on day 160-188 of the year.

In Cracow the pollen season usually starts on the 138th day of the year ( \pm 10 days) (18-19.05). Taking into consideration the minimum (day 107) and maximum (day 147) season start dates, we can say that hypothetically the pollen season may start in the first decade of April (e.g. 1998 and 1999). In comparison to Cracow, in the other Polish cities the grass pollen season start date fluctuated, which was evidenced on the basis of a 5-year study (W e ry s z k o-C h mie lew s ka, 2006).

It is considered that meteorological parameters influence the intensity of plant flowering as well as pollen production and dispersion. The temperature and sunlight conditions have the main impact on the 


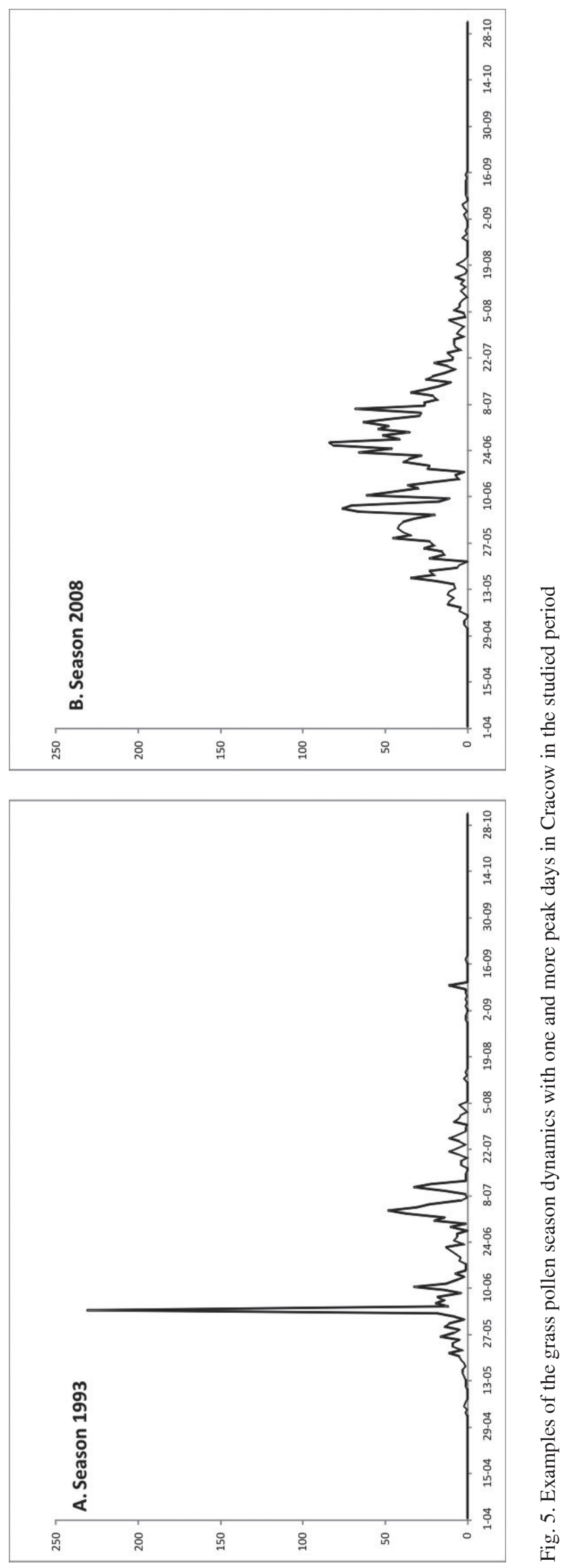




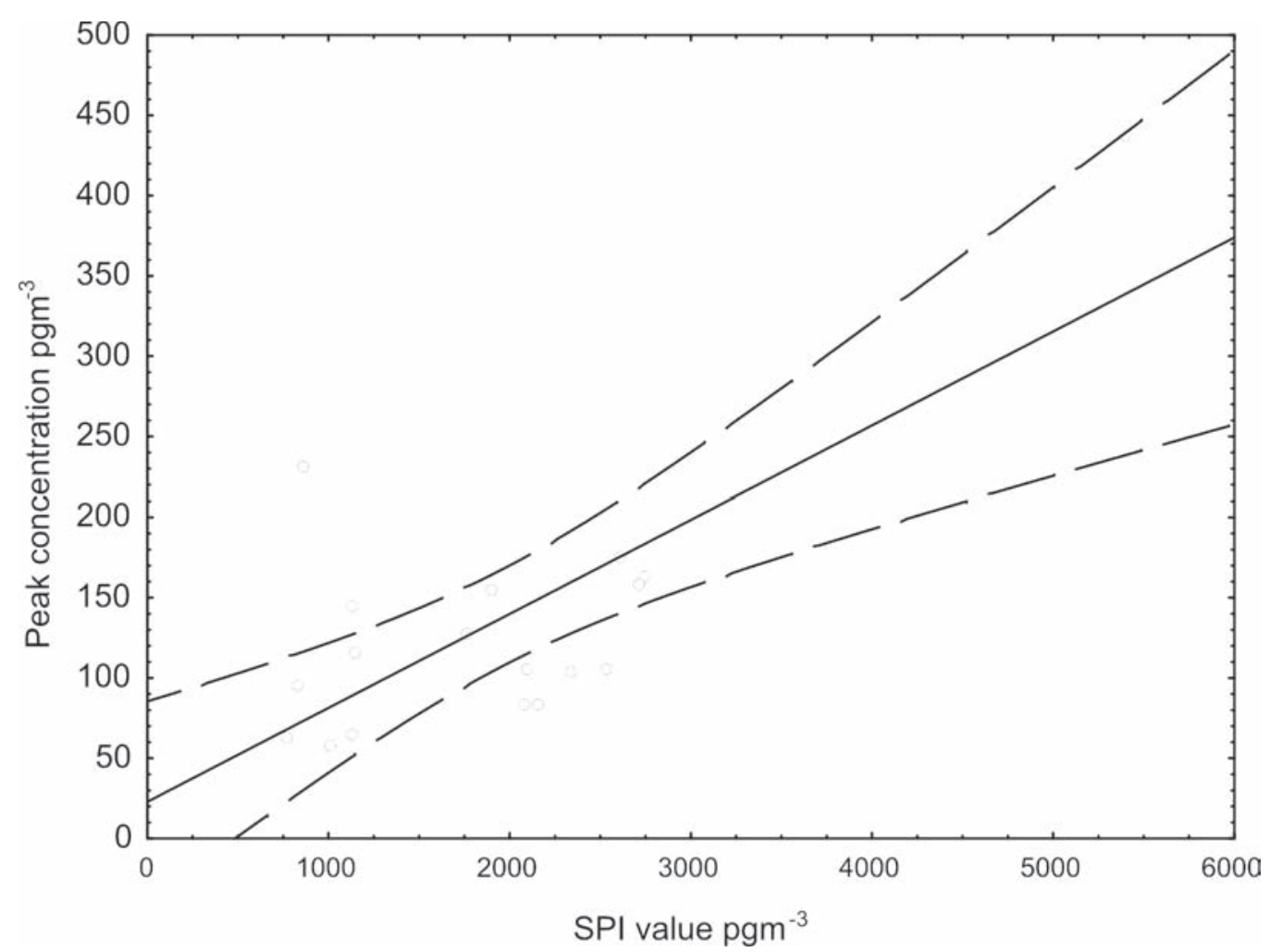

Fig. 6. The relationship between SPI value and peak concentration of grass pollen in Cracow in 1991-2008 $\left(\mathrm{r}_{\mathrm{s}}=0.741 ; \mathrm{p}<0.05\right.$; $\mathrm{R}_{2}=0.552$ )

development of plantgenerativeorgans(F a l k o w s k i, 1982). Pi otrow s a (2006) pointed out the relationship between the season start and the days with mean temperature above $5.6^{\circ} \mathrm{C}$ from the 1 st of March. Peternel (2006) indicated that in Zagreb the grass pollen season started when the mean daily temperature reached $13.5^{\circ} \mathrm{C}$ or maximum daily temperature reached $19.5^{\circ} \mathrm{C}$ and no rainfall was recorded. In Poznań (Western Poland) mean temperature in May and rainfall in March influenced the season start the strongest (S m ith et al. 2009). It was also observed that the North Atlantic Oscillation influenced the grass pollen season, especially in Western Europe ( $\mathrm{S}$ m ith et al. 2009), however in Poznań a relationship between the start and end of the grass pollen season and the mean monthly NAO values was found in December-March.

In Cracow the start of the grass pollen season was affected strongest by mean temperature in the second half of April, between the 101st and 110th days of the year, which refers to the days just before the earliest occurrence of pollen grains. It may be assumed that the mean temperature in April and May has a significant effect on the season start, reaching the mean values in March $\left(-1.53^{\circ} \mathrm{C}\right)$ and in April $\left(-0.55^{\circ} \mathrm{C}\right)$, respectively, in 1991-2008. Similarly to the paper by $\mathrm{S} \mathrm{t} \mathrm{a} \mathrm{c} \mathrm{h} \mathrm{et} \mathrm{al.}$ (2008), we also found a statistically significant relationship between the grass pollen season start and rainfall in April (positive correlation). An increase in rainfall just before the season makes anther opening difficult and in consequence delays the start of the season. Most grasses found in Poland need many hours of sunlight to develop (long-day plants) (F a $1 \mathrm{k} \mathrm{o} \mathrm{w} \mathrm{s} \mathrm{k} \mathrm{i} \mathrm{,} \mathrm{1982).} \mathrm{It}$ has been documented that the sunshine in March-April influences significantly the start of grass flowering. The impact of relative humidity on the season start is known. However, in our study the positive correlation coefficient between humidity and the season start in February (early before the grass pollen season) makes this relationship unclear.

The tendency to earlier pollen season start dates of early-spring flowering plants is explained by the climate changes (mainly the increase in temperature and the greenhouse effect) (S p i e k s m a et al. 2003). At some monitoring sites, a weak trend of earlier grass pollen season start dates was observed (Fre i, 1998; B e g g s , 2004; S t a c h et al. 2008). In Cracow a statistically significant linear trend of earlier season start dates was found. In the studied period (1991-2008), a weak increasing trend in mean temperature between day 101 and 110 from the 1 st of January $\left(\mathrm{r}_{\mathrm{s}} 0.551 ; \mathrm{p}<\right.$ 0.05 ) was found, which had the strongest effect on the season start.

It was observed in Cracow that the coefficient of variation for the start of occurrence of grass pollen and the start of the calculated pollen season were similar (V\% 6.93 vs. 6.92), while for the season and 
calculated by the $95 \%$ method it was about twice as high as for the beginning of pollen occurrence (V\% 6.92 vs. 3.94). It was probably caused by the method of calculation of total pollen season, which limited the examined season to the dense occurrence of airborne pollen (up to the 211th day of the year - the end of July), while in the Mediterranean area the grass pollen season lasts much more longer up to the end of September (P e ternel et al. 2006). The number of meteorological parameters determining the season end is higher than in case of the season start. The dominant parameter seems to be mean temperature in the second decade of April, between days 101 and 110 from the 1st January, between days 141 and 150 (the third decade of May), and between days 171 and 180 from the 1st January (the third decade of June). However, the end of the season was correlated strongest with relative sunshine and cloudiness, especially mean cloudiness in the third decade of June. The influence of sunshine and an increase in temperature accelerate pollen grain release, especially in long-day grass species. On the other hand, the cloudiness delays the season end, particularly at the beginning of August, when only a few grass species release pollen grains.

In the last decade, there occurred an extension of the pollen seasons of the taxa flowering in summer and autumn, including grasses. Emberlin et al. (2000) showed that longer grass pollen seasons were observed towards the north of the Alps. The extension of the seasons is associated with earlier start dates of the pollen seasons and a relatively low variability in season end dates in some regions.

From the medical point of view, the most important phase during the pollen season is the period of high daily concentrations, often including the peak day. Different factors influencing the peak concentration correlated with the SPI value in Cracow. Many grass species release pollen grains at different times. The highest daily concentrations are probably reached at the time when most grass species start pollination or they are in the peak phase of pollination. Relative sunshine in January-March had a considerable impact on peak concentration, despite the fact that these parameters occurred before the season. Similar observations were noted in Poznań (S t a c h et al. 2008), where the time of high concentrations fluctuated between 165 and 179 days (the middle of June). Similarly as in Zagreb (P e t e r n e 1 et al. 2006), we often observed more than one peak, usually in May and July.

The annual total, SPI value and peak concentration are the parameters of high seasonal variability, which is connected with plant physiology (pollen production), human activity, and meteorological conditions. Many authors have described an increasing trend in annual total values, associated more with an increase in $\mathrm{CO}_{2}$ concentration in cities and industrial centres than with an increase in plant community (B e g g s, 2004). Frei (1998) concluded that in Switzerland in 1969-96 mean annual temperature increased from $8.9^{\circ} \mathrm{C}$ to $10.5^{\circ} \mathrm{C}$, which was probably related to the annual grass pollen total increase. In case of the annual total, the trend direction depends on how long the observations were conducted. In Andalusia (G a r c íaMozo et al. 2010) an increasing trend in both annual totals and peak concentrations was observed (in 6 of 8 cities under investigation), in spite of cyclic alternating patterns of these parameters. In Cracow no significant increasing and decreasing trend in the annual total and peak concentration was found. After excluding the SPI value in 1997 (the highest value in examined period) from the analysis, a significant trend was found.

No significant relationship between SPI and temperature as well as between peak concentration and temperature were found in Cracow, whereas these seasonal parameters were influenced by relative sunshine in January-May. Most grass species need many hours of sunlight to develop inflorescences and for pollen production. In Southern Europe the impact of rainfall on the annual total was reported in winter (S á n c h e z M e s a et al. 2003).

\section{COCLUSIONS}

1. The grass pollen season dynamics in Cracow in 1991-2008 was asymmetric, as one or more peak days occurred.

2. Season start and end dates were less variable parameters of the season.

3. The meteorological conditions in the year of observation affected most of the parameters of the grass pollen season.

4. There was found a statistically significant relationship between the SPI value and peak concentration and a weak decreasing linear trend in the time of the season start.

This study was supported by the project grant of the Ministry of Science and High Education No. N305 021236 (2009-2011).

\section{Acknowledgments}

The author would like to thank the Dept. of Climatology, Institute of Geography and Spatial Management, Jagiellonian University for providing meteorological data.

\section{REFERENCES}

Balcerkiewicz S., 2007. Trawy w zbiorowiskach roślinnych Polski. [In]: L. Frey (ed.), Księga polskich traw. W. Szafer Institute of Botany, Polish Academy of Sciences, Kraków: 229-248 (in Polish). 
B eg g s P. J., 2004. Impacts of climate change on aeroallergens: past and future. Clin Exp Allergy, 34:1507-1513.

Carinanos P., Emberlin J., Galán C., DominguesVilches E., 2000. Comparison of two pollen counting methods of slides from a Hirst type volumetric trap. Aerobiologia, 16: 339-346.

D'A mato D., Cecchi L., Bonini S., Nunes C., Annesi-Maesano I., Behrendt H., Liccardi G., Popov T., van Cauwenberge P., 2007. Allergenic pollen and pollen allergy in Europe. Allergy, 62 (9): 976-990.

Dubiel E., 2008. Atlas roślinności rzeczywistej Krakowa. Urząd Miasta Krakowa. Kraków (in Polish).

Emberlin J., Jaeger S., Dominguez-Vilches E., Galan Soldevilla C., Hodal L., Mandrioli P., Rantio-Lehtimäki A., Savage M., Spieksma F. Th., B artlett C., 2000. Temporal and geographical variations in grass pollen seasons in areas of western Europe: an analysis of season dates at sites of the European pollen information system. Aerobiologia, 16: 373-379.

Emberlin J., Mullins J., Cordin J., Jones S., Millington W., Brooke M., Savage M., 1999. Regional variations in grass pollen seasons in the UK, long term trends and forecast models. Clin. Exp. Allergy, 29: 347-356.

Emberlin J., S avage M., Jones S., 1993. Annual variations in grass pollen seasons in London 1961-1990: trends and forecast models. Clin. Exp. Allergy, 23: 911-918.

Falkowski M., 1982. Trawy polskie. Państwowe Wydawnictwo Rolnicze i Leśne. Warszawa (in Polish).

Frei T., 1998. The effects of climate change in Switzerland 1969-1996 on air borne pollen quantities from hazel, birch and grass. Grana, 37: 172-179.

F r e y L., 2007. Taksonomia traw. [In]: L. Frey (ed.), Księga polskich traw. W. Szafer Institute of Botany, Polish Academy of Sciences, Kraków: 39-63 (in Polish).

García-Mozo H., Galán C., Alcázar P., Díaz de 1a Guardia C., Nieto-Lugilde D., Recio M., Hidalgo P., Gónzalez-Minero F., Ruiz L., Domínguez-Vilches E., 2010. Trends in grass pollen season in southern Spain. Aerobiologia, 26: $157-169$.

Gioulekas D., Balafout is C., Damialis A., Papakosta D., Gioulekas G., Patakas D., 2004. Fifteen years' record of airborne allergenic pollen and meteorological parameters in Thessaloniki, Greece. Int. J. Biometeorol. 48: 128-136.

Jato V., Rodríguez-Rajo F. J., Saijo M. C., Aira M., 2009. Poaceae pollen in Galicia (N. W. Spain): characterization and recent trends in atmospheric pollen season. Int. J. Biometeorol. 53: 333-344.

K a s przy k I., 2006. Comparative study of seasonal and intradiurnal variation of airborne herbaceous pollen in urban and rural areas. Aerobiologia, 22: 185-195.

M a t u s zk o D., 2007. Usłonecznienie. [In]: D. Matuszko (ed.), Klimat Krakowa w XX wieku. Kraków: 87-97 (in Polish).
Myszkowska D., 2006. Pyłek wybranych taksonów roślin w powietrzu Krakowa, 2001-2005. [In]: E. WeryszkoChmielewska (ed.), Pyłek roślin w aeroplanktonie różnych regionów Polski. Lublin: 21-30 (in Polish).

Myszkowska D., Bilo B., Stępalska D., Wołek J., Obtułowicz K., 2007. Personal and stationary pollen monitoring wit regard to pollen allergy symptoms. Allergy Clin Immunol Int. 19 (3): 108-114.

Myszkowska D., Stępalska D., Obtułowicz K., Porębski G., 2002. The relationship between airborne pollen and fungal spore concentrations and seasonal pollen allergy symptoms. Aerobiologia, 18: 153-161.

Obtułowicz K., Szczepanek K., Radwan J., Grzywacz M., Adamus K., Szczeklik A., 1991. Correlation between airborne pollen incidence, skin prick tests and serum immunoglobulin in allergic people in Cracow, Poland. Grana, 30: 136-141.

Peternel R., Srnec L., Čulig J., Hrga I., Hercog P., 2006. Poaceae pollen in the atmosphere of Zagreb (Croatia), 2002-2005. Grana, 45: 130-136.

Piotrowicz K., 2007. Temperatura powietrza. / Air temperature. [In]: D. Matuszko (ed.), Klimat Krakowa w XX wieku Kraków: 99-112 (in Polish).

Piotrowicz K., Myszkowska D., 2008. Charakterystyka sezonów pyłkowych wybranych taksonów roślin w Krakowie na tle warunków meteorologicznych. [In]: K. Kłysik, J. Wibig, K. Fortuniak (eds), Klimat i bioklimat miast. Wydawnictwo Uniwersytetu Łódzkiego, Łódź: 301-311 (in Polish).

Piotrowska K., 2006. The effect of meteorological factors on the start of the grass pollen season in Lublin in the years 2001-2004. Acta Agrobot. 59: 365-372.

Sánchez Mesa J.A., Smith M., Emberlin J., Allitt U., Caulton E., Galan C., 2003. Characteristics of grass pollen seasons in areas of southern Spain and the United Kingdom. Aerobiologia, 19: 243-250.

Smith M., Emberlin J., Stach A., Rantio-Lehtimäki A., Caulton E., Thibaudon M., Sindt C., Jäger S., Gehrig R., Frenguelli G., Jato V., Rodríguez-Rajo F. J., A lcázar P., Galán C., 2009. Influence of the North Atlantic Oscillation on grass pollen counts in Europe. Aerobiologia, 25: 321-332.

Spieksma F. Th. M., Corden J. M., Detandt M., Mi11ing ton W.M., Nik kels H., Nolard N., S choenmakers C. H. H., W a ch te r R., de Weger L. A., Willems R., Emberlin J., 2003. Quantitative trends in annual totals of five common airborne pollen types (Betula, Quercus, Poaceae, Urtica, and Artemisia), at five pollen-monitoring stations in western Europe. Aerobiologia, 19: 171-184.

$\mathrm{Stach}$ A., 2000. Variation in pollen concentration of the most allergenic taxa in Poznań (Poland), 1995-1996. Aerobiologia, 16: 63-68.

Stach A., Smith M., Prieto Buena J. C., Ember1 i n J., 2008. Long-term and short-term forecast model for Poaceae (grass) pollen in Poznań, Poland, constructed using regression analysis. Envir. Experimental Bot. 62: 323-332. 
Szczepanek K., 2004. Pollen calendar for Cracow (southern Poland), 1982-1991. Aerobiologia, 10: 65-70.

Valencia-Barrera R. M., Comtois P., FernándezGonzalez D., 2001. Biogeography and bioclimatology in pollen forecasting. An example of grass in León (Spain) and Montréal (Canada). Grana, 40 (4-5): 223 229.

Walanus A., 1994. Statistical analysis of correlations between pollen rain and the weather. Zeszyty Naukowe Uniwersytetu Jagiellońskiego. Prace Geograficzne, 97: 33-46.

Weryszko-Chmielewska E. (ed.), 2006. Pyłek roślin w aeroplanktonie różnych regionów Polski. / Plant pollen in aeroplankton of different regions of Poland. Katedra i Zakład Farmakognozji AM w Lublinie: 31-115.

Woś A., 1999. Klimat Polski. Państwowe Wydawnictwa Naukowe, Warszawa (in Polish).

\section{Dynamika sezonów pyłkowych traw w odniesieniu do warunków meteorologicznych w Krakowie, Pd. Polska, 1991-2008}

\section{Streszczenie}

Celem pracy była analiza dynamiki sezonów pyłkowych traw w Krakowie w latach 1991-2008 oraz znalezienie związku pomiędzy warunkami meteorologicznymi i parametrami sezonu. Średnio sezon za- czynał się w 138 ( \pm 10 dni), zaś kończył w $211( \pm 10$ dni) dniu roku. Mediana sumy ziaren pyłku dla sezonu wyznaczonego metodą 95/90\% (SPI) wyniosła 2041, wartość stężenia maksymalnego - 111 pgm $^{-3}$ (osiągana średnio w 34 dniu sezonu / 173 dniu roku). Temperatura średnia w kwietniu-maju wykazywała największy wpływ na początek i koniec sezonu, dodatkowo na koniec sezonu miała wpływ $\mathrm{T}_{\text {sr }}$ trzeciej dekady czerwca (zależność ujemna). $\mathrm{T}_{\text {sr }}$ kwietnia-maja miała wpływ na datę wartości maksymalnej (korelacja ujemna). Opady deszczu w styczniu i kwietniu miały wpływ na początek sezonu. Usłonecznienie względne w okresie marzec-kwiecień wpływa na początek, w III dekadzie czerwca na koniec sezonu (zależności ujemne). Usłonecznienie w marcu-kwietniu ma wpływ na datę stężenia maksymalnego (zależność dodatnia), natomiast wartości z okresu styczeń-marzec wpływaja na wysokość stężenia maksymalnego (dodatnio). Zachmurzenie w lutym-maju i w III dekadzie czerwca wywiera wpływ na koniec sezonu oraz na datę stężenia maksymalnego (zależność dodatnia). Wilgotność lutego wpływa na początek sezonu (zależność ujemna). Wartość SPI była zależna od usłonecznienia w okresie luty-maj (dodatnio), wilgotności w kwietniu i zachmurzenia w lutym-marcu (negatywnie). 